\title{
THE REGIME OF COWSHED ENVIRONMENT AND GROUND SOILS TEMPERATURE
}

Raimondas ŠADZEVIČIUS, Institute of Hydraulic Engineering, Faculty of Water and Land Management, Aleksandras Stulginskis University, Universiteto str. 10, LT-53361, Akademija, Kaunas distr., Lithuania, raimondas.sadzevicius@ asu.lt (corresponding author) Vincas GURSKIS, Institute of Hydraulic Engineering, Faculty of Water and Land Management, Aleksandras Stulginskis University, Universiteto str. 10, LT-53361, Akademija, Kaunas distr., Lithuania, vincas.gurskis@asu.lt

Rytis SKOMINAS, Institute of Hydraulic Engineering, Faculty of Water and Land Management, Aleksandras Stulginskis University, Universiteto str. 10, LT-53361, Akademija, Kaunas distr., Lithuania, rytis.skominas@asu.lt

Dainius RAMUKEVIČIUS, Institute of Hydraulic Engineering, Faculty of Water and Land Management, Aleksandras Stulginskis University, Universiteto str. 10, LT-53361, Akademija, Kaunas distr., Lithuania, dainius.ramukevicius@asu.lt

The quantity and quality of milk depends not only on milking or milk storage equipment but also on cow's well-being. A cow lying on the animal bed gives a certain amount of heat, as intense heat exchanges occur on the ground through the floor. When lying, the blood in the cow's udder flows more intensely. It is known that for the formation of one liter of milk 500 liters of blood should flow through the cow's udder. The amount of milk is highly dependent from the micro-climate of the animal's bed, during the rest of the cow. The poorly installed or inappropriately designed bearing bed's floors do not meet the physiological needs of the animals from a thermal point of view, much more energy loss occurs. Often there are cases where cold-frozen animals suffer from various cold diseases and their productivity decreases. Therefore, no less attention should be paid to the cow's bed floor.

The article analyses the temperature regime of the base of the cowshed and the ground of its environment during the regular period. The structure of the cowshed building is energy-heated, with bearing vault structures. Cows are kept tied up in re-bars. The floor of the cowshed room is installed on the ground. The ground floor temperature is fixed in 3 boreholes under the floor and also in 3 wells near the cowshed ground. Temperatures were fixed up to 6 meters deep. The fields of distribution of the base of the cowshed and its ground temperature are established during the regular period.

Analysis of the temperature of the base of the cowshed and its environment showed that the ground temperature is influenced by the amount of heat released by the animal, which transmits itself not only to the room, but also to the base ground through the floor of the bearing bed. Since the bed's floor is installed on the ground, the amount of heat loss caused by the animal through the floor depends not only on the thermal properties of the floor, but also on the base ground temperature regime. Extremely intense heat exchanges through the base ground occur during the coldest period of the year.

Keywords: cows, cowshed, ground, temperature.

\section{INTRODUCTION}

One of the main criteria for animal husbandry is animal welfare. Livestock must be healthy and have normal environmental conditions. One of the main conditions of an animal's well-being is its stable temperature status (Nilsson, 1992; Kavolelis, Sateikis, 2004; Pajumägi et al, 2008). The livestock, like all living organisms, is thermodynamically an open energy system with an internal heat source. The constant temperature of the animal's body is supported by complex physiological mechanisms that regulate heat production and release. The thermal balance of the animal body is partly determined by environmental conditions. Therefore, due to the change in environment temperature, the intensity of heat exchange between the animal and its surrounding environment is also changing. Environmental factors are important to protect animals from harmful effects. One of the factors influencing the normal animal's well-being is the bed floor.

The animal's bed is a place where the animal is resting without injuries and stress. When improving livestock storage technologies and techniques special attention is paid to the floors of the bed. The health and productivity of the animal depends on the thermal properties of the bed floor. Cows spend 50-60\% of their time lying on their beds. Their contact area with the floor reaches 1/5-1/6 part of the body surface. The constant body temperature of the animal ensures the normal functioning of its body. However, this process can be disrupted if the animal lays on a cold floor (Sallvik, 1998; Kavolelis, Bleizgys, 2006). In this case, the animal is subject to dual environmental conditions to which its body can not fully adapt, i.e. on one side of the body will break blood vessels and remove warm blood from the surface of the 
skin, and at the same time there will be normal blood vessels functioning in other parts of the body (Nilsson, 1988). The chilling of individual parts of animal's skin temporarily reduces their temperature. A temporary decrease in temperature in the parts of the cow appears in shrinkage of circulating vessels, thus reducing blood flow to the udder. In this case, the bed floor does not meet the physiological needs of the animal from the thermal point of view, the animal suffers much more energy losses (Hautala et al, 2001).

The temperature of the animal's bed floor is lower than the body temperature of the animal. It is an advantage in the heat, but when it's cold in the cowshed it's a big drawback (Turnpenny et, al., 2006). When the animal falls on a cold floor, an intense heat flow to the floor forms. When the floor is installed on the ground, the heat flow to the floor depends not only on the thermal properties of the floor, but also on the temperature of the ground floor of the building. Changing the heat exchange from the animal through the bed floor can affect the animal's heat exchange with the environment. In order to achieve this purpose, it is necessary to assess the influence of the temperature regime of the ground in the environment that is directly influenced by meteorological conditions.

The aim of this paper to assess the influence of the temperature regime in soils of cowshed environment (directly influenced by the weather conditions) on the temperature field of the ground under base of building.

\section{WORK METHODOLOGY}

The configuration of building, lodgment lay, arrangement of windows and doors, animal resting and standing places have been taken into account as the potential factors of outdoor influence when selecting the place in the object for the measuring of the soil temperature. 80 places two-lines for cows keeping insulated cowshed was selected for experimental research. The cows keeping system is a barnhouse and pasture. For analysis the data of investigations performed during the 2012-2013 period were used.

The length of the cowshed is $66,6 \mathrm{~m}$, width $-12,5 \mathrm{~m}$, height of the lodgment $-2,4 \mathrm{~m}$. Constructions of the cowshed: foundations - concrete stripped, width $-40 \mathrm{~cm}$, depth $-1,1 \mathrm{~m}$; outside walls - the masonry without air gap, thickness $51 \mathrm{~cm}$, the inside - ceramic bricks and outdoor side - silicate bricks; windows - from glass with wooden frames; overlay - assembled reinforced concrete slabs, insulated with the $15 \mathrm{~cm}$ layer of slag; roof - from timber material; coating - wavy asbestos cement sheets and laths. Floor construction: concrete $-5 \mathrm{~cm}$; gravel $-15 \mathrm{~cm}$; ground soil - clay.

6 measurement point places have been picked in the investigated object. The cowshed plan is presented in Figure 1. It is very important to evaluate the influence of the foundation when investigating the temperature state of ground soils. The borings must be arranged very close to the foundation from the inside as well as from the outdoor side places for that reason. The soil temperature nearby building should be taken into account when trying to evaluate the influence of soil in building zone on the temperature state of the whole building.

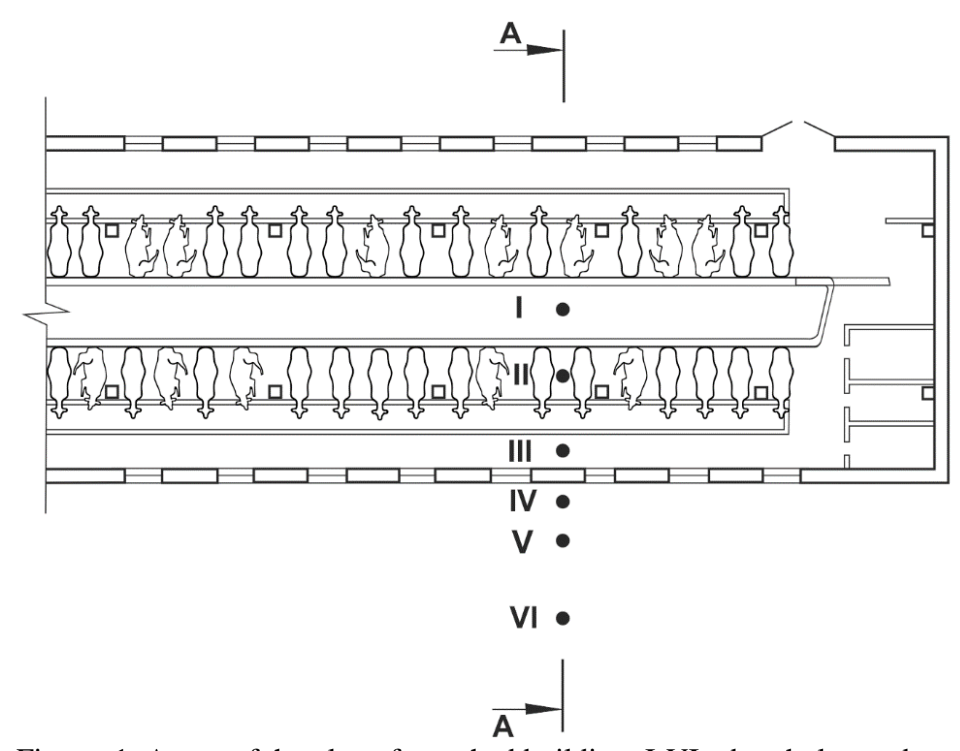

Figure. 1. A part of the plan of cowshed building: I-VI - borehole numbers

3 borings (with diameter of $4 \mathrm{~cm}$ ) from inside (No. I, II, III) and 3 borings (No. IV, V, VI) from the outside of the cowshed with location from the middle of the cowshed to the foundation have been taken for the soil temperature investigations. Semiconductor transistor sensors have been left in every boring for the measurement of the temperature in vertical direction at a distances of $0.25 \mathrm{~m}, 0.5 \mathrm{~m}, 1.0 \mathrm{~m}, 2.0 \mathrm{~m}, 3.0 \mathrm{~m}, 4.0 \mathrm{~m}, 5.0 \mathrm{~m}, 6.0 \mathrm{~m}$ from the ground surface. In the outdoor of the building at a distances of $0.6 \mathrm{~m}, 2.0$ and $5.0 \mathrm{~m}$ from the outdoor wall and in borings No. IV, V, VI, mentioned sensors have been left to duplicate depth of the ground surface. All borings up to the ground surface were filled up with the mix of sand and gravel (Figure 2).

The data of outdoor temperature monitoring from the Noreikiškès meteorological station located in Kaunas district were used for the research. The meteorological station is about $1 \mathrm{~km}$ away from the research site. 


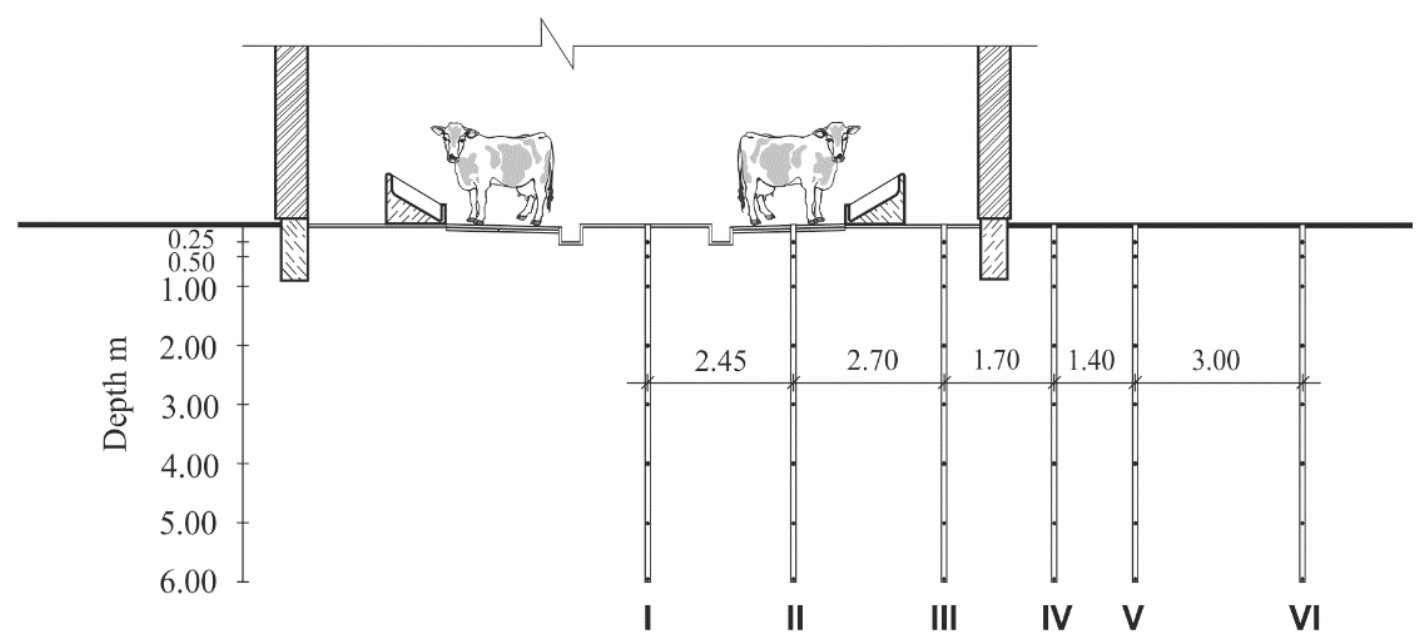

Figure 2. Arrangement of the measuring boreholes of the ground temperature in the cowshed internal base and external environment as well as temperature sensing depths in them (the section A-A)

\section{RESULTS AND DISCUSSION}

During the research period, the average outdoor air temperature was significantly higher than the multiannual average one. In Kaunas area, the multiannual average temperature is $+6.3^{\circ} \mathrm{C}$, while during the research period it was $+7.3^{\circ} \mathrm{C}$. The difference was $1.0^{\circ} \mathrm{C}$ higher.

Measurements of the cowshed floor and ground temperatures as well as the temperature regime in soils of cowshed surrounding showed that the soil temperature below the building is in a constant dynamic state. The heat exchanges between the outside and under the building soils and the floor above them occur due to the external temperature regime.

Extremely intense heat exchanges occur in the livestock building during winter, spring and autumn periods. For example, in January, when the outside temperature drops to $-5^{\circ} \mathrm{C}$, the ground soil temperature drops to $8-12^{\circ} \mathrm{C}$ under the floor. At that time, the temperature of floor surface near the foundation are $1.5-3.0^{\circ} \mathrm{C}$ lower than the floor surface the middle of the cowshed. When the outside temperature is even more lower, the cooling of the ground soil and the floor are partly due to the coldness of the outer wall, because the total thermal resistance of the outdoor wall is quite small $\left(\mathrm{R}_{\mathrm{t}} \approx 1\right.$ $\mathrm{m}^{2} \cdot \mathrm{K} / \mathrm{W}$ ). In this case, when the outside temperature drops by more than $-10^{\circ} \mathrm{C}$, the floor temperature at the foundation is by $3^{\circ} \mathrm{C}$ lower than that of the indoor.

In the livestock barn, the temperature range of the floor surface in the middle of the storage room was $14^{\circ} \mathrm{C}$, at the cows' standing place (bed) $-8^{\circ} \mathrm{C}$ and inside the building at the outer walls - even $18^{\circ} \mathrm{C}$. In summer, for example, in July, due to the influence of solar thermal radiation on the floor, the temperature rises up to $22^{\circ} \mathrm{C}$ and is higher in the period of a few days in comparison with the temperature of indoor floor.

An analysis of the surface temperature of the cowshed building bed floor has shown that the temperature evolution is not constant during the year from the measurement of temperature to the next measurement. The reason for this could be not only the change in the outdoor and indoor air temperature, but also the position of the animal before the measurement of the surface temperature of the floor. If the animal was lying for a while or vice versa - it was a lot of time standing, or perhaps it was not at all for a while in the resting place, because of such actions, the surface temperature of the floor (bed) would suddenly change.

The computer program "Surfer" was used for graphical presentation of the subsoil temperature distribution at the base of the cowshed building and its environment. This program, using data from experiments on ground soils of the cowshed building, obtained the uniform lines of isotherms for the distribution of ground soil temperature of the cowshed building. The whole of these lines forms an isothermal surface. The temperature difference and the distance between the two isotherms gives a temperature gradient that indicates the heat propagation. The directions of the heat propagation from the higher temperature area to the lower one, the ground of the cowshed building and the soil in its environment are indicated by arrows (Figures 3 and 4).

The nature of the variation in the temperature of the ground soil of the cowshed building and its environment during one year is given in Figure 4. They show only the temperate fields of the more typical months. The soil temperature changes (with the changes of the outdoor air temperature) in August are presented in Figure 3, and in Figure 4 - the temperature changes in December. After analyzing the results of soil temperature measurements in the building environment, it was found that in the winter time the depth of freezing (in the furthest point from the building) in the borehole (ground temperature measuring point No. VI) was only $0.25 \mathrm{~m}$. The temperature of the outside air temperature of the investigated winter period is much lower than that of the perennial average air temperature. Meanwhile, in the investigated area, the maximum depth of freezing (possible only once every 10 years) is $0.9 \mathrm{~m}$. Such a deep freezing of the soils could have affected the temperature of the ground soil of the cowshed building. Therefore, it can be argued that for some part the temperature of the ground soil of the cowshed building depends on the temperature of the outdoor air. 
However, experimental studies of the ground soil temperature of the cowshed indicate that the heat of the animals in their standing places also has a significant influence on the building' ground soil temperature.

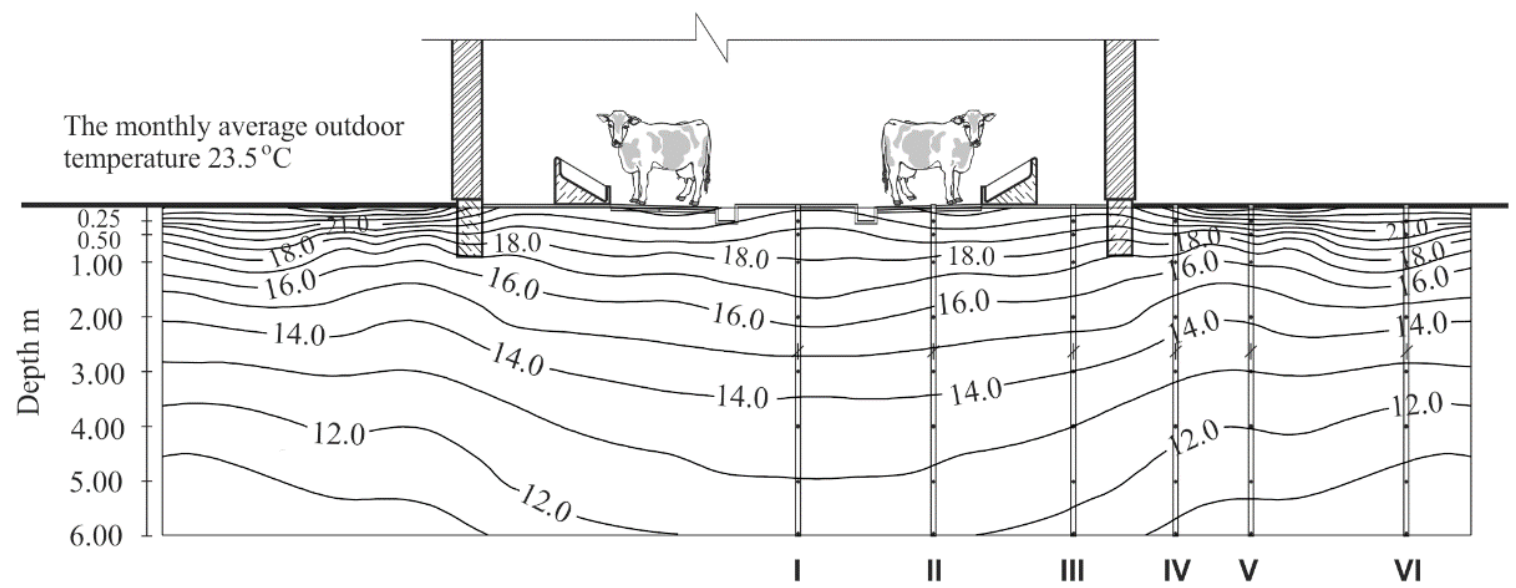

Figure 3. The average ground temperature of the cowshed base and its environment, when the warmest month of outside air temperature was during the research period (month of August)

This is evident in Fig. 4, where the highest temperature per year is at the surface of the bed floor (II ${ }^{\text {nd }}$ ground temperature measurement point). At the animal's standing place, the heat emitted by it passes not only to the surrounding surfaces and the bed floor, but also to the deeper layers of the ground soil. Especially intensive heat exchanges between the animal bed and the building's ambient air through the ground soil and the foundation of the building occurs during the cold period. However, not all heat is transmitted in the aforementioned direction. Part of the animal exposed heat through the floor of the bed to the ground returns to the room due to the difference in temperature between the ground soil and the room air in the other floor area, i.e. not through the floor of the animal bed.

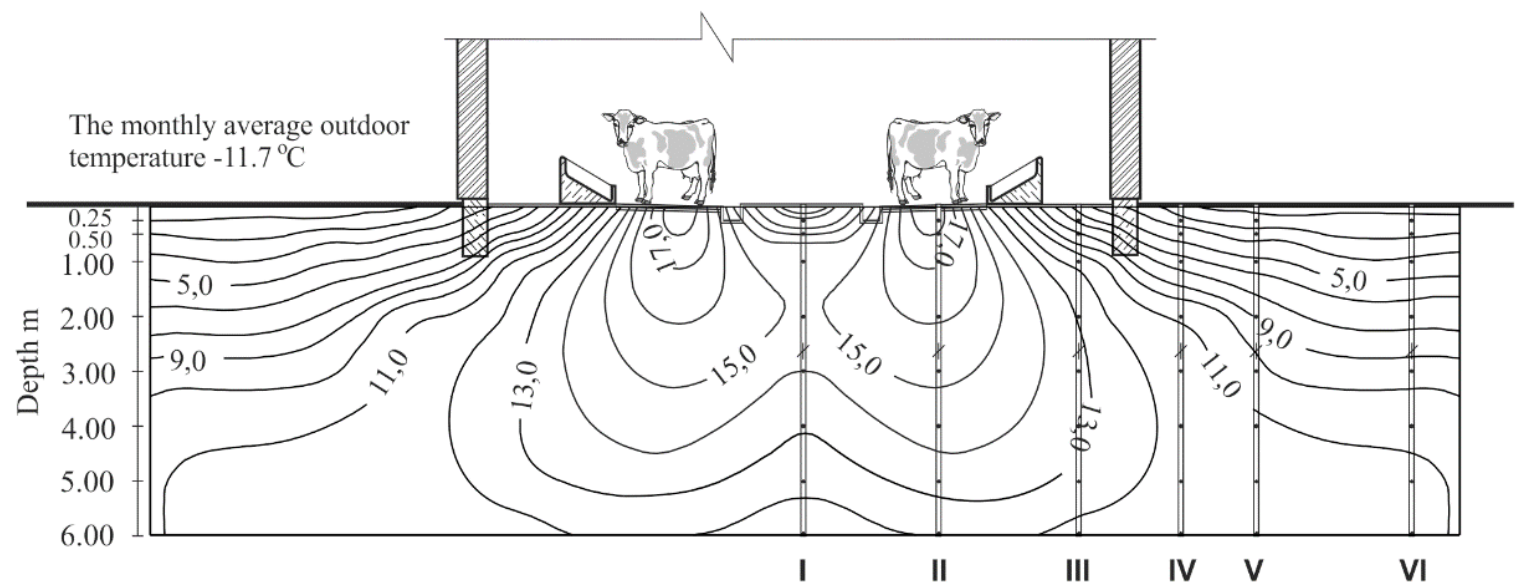

Figure 4. The average ground temperature of the cowshed base and its environment, when the coldest month of outside air temperature was during the research period (the month of December)

\section{CONCLUSIONS}

The highest temperature of the cowshed's building floor surface is in the livestock areas and varies from $14^{\circ} \mathrm{C}$ to $22^{\circ} \mathrm{C}$ per year.

The largest change in ground temperature during the year is set at the foundation of building. Here, during different seasons of the year, the ground temperature changed to a depth of $6.0 \mathrm{~m}$ from $3^{\circ} \mathrm{C}$ to $8^{\circ} \mathrm{C}$.

A more pronounced fluctuation of the ground temperature of the cowshed soil is observed at the depth of up to 3 $\mathrm{m}$. Below this depth the temperature ranges only by $1-2^{\circ} \mathrm{C}$.

The heat accumulated in the ground of the cowshed's building during the cold season is spreading in various directions, including through the floor to the premises, i.e. partly returns to the room. So, the ground soil affects the floor temperature.

\section{REFERENCES}

1. Hautala, M., Ahokas, J. 2001. Heat Transfer from Cow to Floor: Theory and Experiment. Agricultural Machinery, Building and Energy Engineering / EAU Transactions, pp. 64-69. 
2. Nilsson, C. 1988. Floors in Animal Houses: Report No. 61 Swedish University of Agricultural Sciences. Department of Farm Buildings. - Lund.

3. Nilsson, C. 1992. Walking and Lying Surfaces in Livestock Houses. C. Piggins \& D. Piggins, Farm Animals and the Environment. CAB International. Wallingford, p.94-99.

4. Kavolelis, B., Bleizgys, R. 2006. Neapšiltintos karvides optimalus temperatūrinis-dregmes režimas. Journal of Environmental Engineering and Landscape Management, Vol. 14, Iss. 2, pp. 89-94.

5. Kavolelis B., Sateikis I. 2004. Effective cowshed insulating and ventilation system parameters. Energy and Buildings, Vol. 36, pp. 969-973. https://doi.org/10.1016/j.enbuild.2004.04.001

6. Pajumägi, A., Poikalainen, V., Veermäe, I., Praks, J. 2008. Spatial distribution of air temperature as a measure of ventilation efficiency in large uninsulated cowshed. Building and Environment, Vol. 43, Iss. 6, pp. 1016-1022. https://doi.org/10.1016/j.buildenv.2007.02.015

7. Sallvik, K.G. 1998. Environment for Animals. CIGR Handbook of Agricultural Engineering. Animal Production. Volume II. Publisher by: American Society of Agricultural Engineers.

8. Turnpenny, J.R., Wathes, C.M., Clark, J.A., McArthur, A.J. 2006. Thermal balance of livestock: 2. Applications of a parsimonious model. Agricultural and Forest Meteorology, Vol. 101, Issue 1, pp. 29-52. https://doi.org/10.1016/S01681923(99)00157-4 